\title{
Article \\ The Role of Laccase from Zygomycetous Fungus Mortierella elasson in Humic Acids Degradation
}

\author{
Alexander Lisov ${ }^{1, *}$, Oksana Belova ${ }^{1}$, Anna Zavarzina ${ }^{2}$, Andrey Konstantinov ${ }^{2}$ and Alexey Leontievsky ${ }^{1}$ \\ 1 Federal Research Center "Puschino Scientific Center for Biological Research of the Russian Academy of \\ Sciences", G.K. Skryabin Institute of Biochemistry and Physiology of Microorganisms RAS, \\ 142290 Pushchino, Russia; olennna@gmail.com (O.B.); lisov@ibpm.pushchino.ru (A.L.) \\ 2 Moscow State University, Faculty of Soil Science, Faculty of Chemistry, 119992 Moscow, Russia; \\ zavarzina@mail.ru (A.Z.); noogen@inbox.ru (A.K.) \\ * Correspondence: ssl208@rambler.ru
}

check for updates

Citation: Lisov, A.; Belova, O.; Zavarzina, A.; Konstantinov, A.; Leontievsky, A. The Role of Laccase from Zygomycetous Fungus Mortierella elasson in Humic Acids Degradation. Agronomy 2021, 11, 2169. https://doi.org/10.3390/ agronomy11112169

Academic Editors: Evgeny Lodygin;

Evgeny Abakumov and

Elena Shamrikova

Received: 30 September 2021

Accepted: 26 October 2021

Published: 28 October 2021

Publisher's Note: MDPI stays neutral with regard to jurisdictional claims in published maps and institutional affiliations.

Copyright: (c) 2021 by the authors. Licensee MDPI, Basel, Switzerland. This article is an open access article distributed under the terms and conditions of the Creative Commons Attribution (CC BY) license (https:/ / creativecommons.org/licenses/by/ $4.0 /)$.

\begin{abstract}
Biochemical stability of soil humus is an important factor affecting soil quality. Fungi are among the most efficient decomposers of humic matter due to presence of oxidative enzymes, including phenoloxidase laccase. Production of laccase by zygomycetes, a group of cellulolytic fungi widespread in soil, is poorly studied. The potential role of laccase from zygomycetes in humus turnover is unknown. Here, we show for the first time that laccase of zygomycetous fungus Mortierella elasson can effectively depolymerize humic acids in vitro. The fungus produced laccase extracellularly in a liquid culture medium. Unlike in case of laccases in ligninolytic basidiomycetes, attempts to increase enzyme activity using inductors, changes in the source of nitrogen and carbon failed to lead to any increase in laccase production. Laccase was purified using ion exchange chromatography and gel filtration. The molecular weight of the laccase was $51.75 \mathrm{kDa}$. The laccase catalyzed the oxidation of ABTS and $\mathrm{K}_{4}\left[\mathrm{Fe}(\mathrm{CN})_{6}\right]$, phenolic compounds, but not tyrosine. The laccase activity was inhibited by $\mathrm{NaN}_{3}$ and $\mathrm{NaF}$. The $\mathrm{pH}$ optimum of the laccase activity was 3.0 for ABTS and 5.0 for 2,6-dimethoxy phenol. The enzyme had moderate thermal stability and was rapidly inactivated at $70{ }^{\circ} \mathrm{C}$. Purified laccase depolymerized humic acids from retisol, compost and peat more effectively than culture liquid containing laccase. The results of the study extend our knowledge of the role of laccases from different producers in the transformation of natural organic matter.
\end{abstract}

Keywords: soil organic matter; decomposition; humic substances; laccase; cellulolytic fungi

\section{Introduction}

Soils store about $1500 \mathrm{Gt}$ of organic C in one meter layer [1]. Stability and persistence of this huge organic matter pool depends on the chemical structure of compounds, bioclimatic conditions and soil management practices controlling microbial activities $[2,3]$.

Humic acids (HA-alkali-soluble, acid-insoluble components of humus) serve as the characteristic and quantitatively significant operational fraction of humus comprising $10-40 \%$ of $\mathrm{C}_{\text {org }}$ in humus horizons [4]. This fraction is largely represented by polar hydrophylic compounds bearing carboxylic and phenolic moieties. In mineral soil horizons the majority of these humic constituents are stabilized by interaction with soil mineral matrix. Destabilization of these polar compounds under soil management practices can lead to substantial carbon losses. It is important to understand biochemical controls for stability of these abundant humus components in order to better predict the dynamics of soil organic matter (SOM) under natural- and anthropogenically-induced disturbances.

Transformation and degradation of organic debris and humic matter is largely an oxidative process with fungi playing a key role. Fungi are active producers of extracellular oxidative enzymes, including laccase [5]. Laccase (benzenediol:oxygen oxidoreductases, EC 1.10.3.2) is an enzyme belonging to the group of copper-containing oxidases which contain copper ions in the active center. Laccase catalyzes oxidation of a wide range 
of substrates by molecular oxygen, which is reduced to water during the reaction [6]. Substituted phenols, aromatic amines, dyes, and metal ions can act as laccase substrates [7,8]. Substituted phenols, excluding tyrosine, but including soil humic acids (HA-alkalisoluble, acid-insoluble humus components), are among the common substrates for laccase [9-11]. Phenoxy radicals and quinones produced during catalytic stage of substrate oxidation can undergo spontaneous coupling reactions leading to substrate polymerization. Reactive oxygen species produced by laccase can initiate C-C bonds cleavage and depolymerization of large molecular weight phenols to lower molecular weight compounds [12] Thus, laccase plays a bifunctional role in the transformation of phenolic substrates.

Laccase is widespread among various organisms. It is found in plants, insects, algae [13-15] and in many bacteria, where it occurs in two forms-as two-domain and three-domain protein $[16,17]$. Laccase is most widely distributed in fungi and has been characterized in many representatives of the divisions Basidiomycota and Ascomycota [7,18]. Laccase performs various functions in living organisms. In plants, laccase is involved in the synthesis of lignin and the metabolism of flavonoids $[19,20]$. In fungi and bacteria, laccase is involved in melanin biosynthesis [21,22]. Extracellular fungal laccase is a part of lignindegrading system in the white-rot fungi and it has been shown that the enzyme is involved in lignin degradation [23,24]. At the same time the enzyme is involved in polymerization of low-molecular lignin decomposition products that may be toxic to lignin-decomposing fungi [12].

Laccase activity is high in soils [25]. It has been shown that fungal and bacterial laccases are involved in the formation of dark-colored heterostructures (known as humic substances, HS) via free-radical condensation reactions [5,26,27], while laccases of white-rot fungi can depolymerize alkali-soluble humus components (HA) as effectively as ligninolytic peroxidases do [11]. Most of the studied laccases belong to divisions Basidiomycota and Ascomycota, which are widely represented in soils $[28,29]$. The production of laccase by other fungal taxa and their role in humus turnover has been much less investigated. Laccase genes are found in many fungal genomes, including the genomes of zygomycete fungi [30]. Zygomycete fungi were previously referred to the single phylum, Zygomycota. At present, this phylum has been abandoned and, based on phylogenetic analyses of a genome-scale data, divided into several phyla [31]. One of these is phylum Mucoromycota. Representatives of this phylum are widely represented in soils. This determines their potential participation in the humus turnover. Production of laccase by fungi of this systematic group has been shown only in few representatives of genera Mucor and Rhizopus [32,33]. The laccase of fungus Mucor circinelloides was partially purified and characterized [34]. The role of laccases of zygomycete fungi in the transformation of humic matter has never been studied so far.

In this work, we have purified laccase of the fungus Mortierella elasson and studied its role in the transformation of humic acids of different origin and composition. Genus Mortierella belongs to phylum Mucoromycota. Fungi of this genus are common in soils and on plant roots [35]. Fungus M. elasson has been isolated from pineapple roots [36]. We have studied the conditions of production of laccase by the fungus and characterized the properties of the enzyme. We show for the first time that laccase from a representative of zygomycete fungi can depolymerize HA both in the liquid fungal culture and in vitro. The results of the study extend our knowledge on the role of laccases from different producers in the humus turnover.

\section{Materials and Methods}

2.1. Strain, Media and Culture Conditions

2.1.1. Inoculum Preparation

The Mortierella elasson VKM F-1406 strain was obtained from the All-Russian Collection of Microorganisms (http://www.vkm.ru/index.htm accessed on 26 October 2021) on December 2017. The strain was maintained at $4{ }^{\circ} \mathrm{C}$ on malt agar with monthly replanting of the strain. For inoculation of a liquid medium, a culture was used, which was grown on a following medium (g/L): peptone $-2 ; \mathrm{NH}_{4} \mathrm{NO}_{3}-0.5$, glucose -2 ; yeast extract -1 , malt 
extract-1. This medium in a volume of $100 \mathrm{~mL}$ was infected with three pieces of mycelium $1 \mathrm{~cm}$ in diameter, and then the culture was grown at $28{ }^{\circ} \mathrm{C}$ for 7 days with stirring at $100 \mathrm{rpm}$. Then, the fungal mycelium was washed with sterile medium and crushed using sterile porcelain beads. Crushed mycelium in a volume of $5 \mathrm{~mL}$ was used for inoculation of $200 \mathrm{~mL}$ of liquid medium.

\subsubsection{Induction of Laccase}

For experiments on induction of laccase, the following media were used. Medium 1 was prepared in $5 \mathrm{mM}$ K-phosphate buffer ( $\mathrm{pH}$ 6.0) and had the following composition (g/L): $\mathrm{NH}_{4} \mathrm{NO}_{3}-0.2 ; \mathrm{MgSO}_{4}-0.1$; peptone-0.5; soy flour-0.5; glycerol—4. Medium 2 was prepared in distilled water and contained the following $(\mathrm{g} / \mathrm{L})$ : peptone-1; yeast extract-1; $\mathrm{KH}_{2} \mathrm{PO}_{4}-0.3 ;\left(\mathrm{NH}_{4}\right)_{2} \mathrm{SO}_{4}-0.5$; glucose-2. Medium 3 was prepared in $20 \mathrm{mM}$ Na-tartaric buffer $\mathrm{pH} 4.5$ and contained the following $(\mathrm{g} / \mathrm{L}): \mathrm{CaCl}_{2}-0.01 ; \mathrm{MgSO}_{4}-0.1$; $\mathrm{KH}_{2} \mathrm{PO}_{4}-0.3$; glucose-2. It was used in two variants-with a high nitrogen concentration $(\mathrm{HN})$ and a low nitrogen concentration (LN). The nitrogen sources were added in the following quantity $(\mathrm{g} / \mathrm{L})$ : $\alpha$-asparagine $-0.9 ;-0.5$ for $\mathrm{HN}$ medium and $\alpha$-asparagine -0.09 ; $\mathrm{NH}_{4} \mathrm{NO}_{3}-0.05$ for $\mathrm{LN}$ medium.

To study the effect of inductors on laccase production the following substances were used: 2,5-xylidine, guaiacol (2-methoxyphenol), 2,6-DMP, ferulic acid, veratrole alcohol (3,4-dimethoxybenzyl alcohol), vanillic acid, anthranilic acid (2-aminobenzoic acid), syringic acid (4-hydroxy-3,5-dimethoxybenzoic acid), gallic acid (3,4,5-trihydroxybenzoic acid, $\mathrm{Cu}^{2+}$ and $\mathrm{Mn}^{2+}$ ions. Inductors were introduced into media 1-3 at a concentration of 0.1 or $0.5 \mathrm{mM}$ at the beginning of cultivation. The aromatic substances were dissolved in $96 \%$ ethanol and introduced into the medium; the solutions of $\mathrm{CuSO}_{4}$ and $\mathrm{MnSO}_{4}$ were sterilized by filtration.

\subsection{Enzyme Purification}

Laccase purification was carried out in several stages. Stage 1: precipitation with $\left(\mathrm{NH}_{4}\right)_{2} \mathrm{SO}_{4}$ to $90 \%$ of saturation followed by centrifugation-15,000 $\times \mathrm{g}$ for $30 \mathrm{~min}$. The precipitate was redissolved in $20 \mathrm{mM}$ Tris- $\mathrm{HCl}$ buffer, $\mathrm{pH} 7.5$ (buffer A), and dialyzed against the same buffer (10 kDa membrane). Stage 2: ion exchange chromatography on a column $($ size, $\mathrm{cm}$, length $\times$ diameter $-30 \times 1.5$ ) with DEAE-Sepharose Fast Flow $(\mathrm{GE}$ Healthcare, Chicago, IL, USA). The crude enzyme preparation after the dialysis step was loaded onto a column equilibrated with buffer $\mathrm{A}$, the column was washed with three volumes of the same buffer and the protein was eluted at a rate of $1 \mathrm{~mL} / \mathrm{min}$ with a linear gradient of 0-1 M NaCl. Stage 3: purification on an ion exchange UNOQ6 column (Bio-Rad, Hercules, CA, USA). The column was equilibrated with buffer A, loaded with enzyme preparation and then washed with equilibration buffer. Elution was carried out with a linear gradient of buffer A with $0-0.5 \mathrm{M} \mathrm{NaCl}$, the length of the gradient was 10-20 mL, and the flow rate during elution was $0.5 \mathrm{~mL} / \mathrm{min}$. Stage 4 : gel filtration on a column (size, $\mathrm{cm}$, length $\times$ diameter-100 × 2) with Sephacryl S-200 HR gel (GE Healthcare, Chicago, IL, USA). Fractions with laccase activity obtained after ion exchange chromatography (stage 3) were subjected to gel filtration on a column equilibrated with buffer A containing $0.15 \mathrm{M}$ $\mathrm{NaCl}$. After the gel filtration, fractions with laccase activity were pooled and dialyzed against buffer A. The resulting laccase preparation was dialyzed against buffer $\mathrm{A}$ and used in further work.

\subsection{Enzyme Characterization}

\subsubsection{Enzyme Activity}

Routine measurements of laccase activity were carried out by oxidation of $1 \mathrm{mM}$ 2.2-azino-bis-(3-ethylbenzthiazolin-6-sulfonate) (ABTS) in $20 \mathrm{mM} \mathrm{Na}$-acetate buffer, $\mathrm{pH}$ 4.5. The progress of the reaction was observed spectrophotometrically by the formation of products at $420 \mathrm{~nm}\left(\varepsilon 420=36,000 \mathrm{M}^{-1} \times \mathrm{cm}^{-1}\right)$ [37]. One unit of laccase activity 
was defined as the amount of laccase that catalyzed the oxidation of one micromole of a substrate per one minute.

\subsubsection{Optimal $\mathrm{pH}$ and $\mathrm{pH}$ Stability}

Optimal $\mathrm{pH}$ was determined in $50 \mathrm{mM}$ Britton-Robinson buffer. The $50 \mathrm{mM}$ BrittonRobinson buffer was prepared by mixing equal amounts of $0.05 \mathrm{M}$ boric, $0.05 \mathrm{M}$ orthophosphoric, and $0.05 \mathrm{M}$ acetic acids and by $\mathrm{pH}$ adjustment to the required value using $1 \mathrm{M}$ $\mathrm{NaOH}$. To determine the optimum $\mathrm{pH}$ of laccase, the activity was measured within the $\mathrm{pH}$ range from 2.0 to 8.0. When determining the $\mathrm{pH}$ stability, laccase was placed into $50 \mathrm{mM}$ Britton-Robinson ( $\mathrm{pH} 1.0-8.0$ ) to attain a final concentration of $0.1 \mathrm{mg} / \mathrm{mL}$ and sterilized by filtration. The initial activity of the enzyme was measured, then the enzyme preparation was incubated for 4 days at $4^{\circ} \mathrm{C}$ and the residual activity of the enzyme was measured.

\subsubsection{Temperature Optimum and Thermal Stability}

The temperature optimum of the enzyme activity was determined by measuring initial rate of the oxidation of ABTS in $20 \mathrm{mM} \mathrm{Na}$-acetate buffer, $\mathrm{pH}$ 4.5. To study thermal stability, laccase was incubated in a buffer at different temperatures. At certain time intervals, samples were taken from the incubation mixtures and the residual activity was measured.

\subsubsection{Kinetic Constants of Substrate Oxidation}

Calculation of the apparent kinetic constants was performed by nonlinear regression of data using Sigma Plot 11.0 software. To calculate the activity, the molar extinction coefficients were used: $\varepsilon 469=49,600 \mathrm{M}^{-1} \times \mathrm{cm}^{-1}$ for 2.6-dimethoxyphenol (2.6-DMP) [38], $\varepsilon 420=1020 \mathrm{M}^{-1} \times \mathrm{cm}^{-1}$ for $\mathrm{K}_{4}\left[\mathrm{Fe}(\mathrm{CN})_{6}\right.$ ] [39], $\varepsilon 470=26,600 \mathrm{M}^{-1} \times \mathrm{cm}^{-1}$ for 2-methoxyphenole (guaiacol) [40] and $\varepsilon 248=17,252 \mathrm{M}^{-1} \times \mathrm{cm}^{-1}$ for hydroquinone (benzene-1.4diol) [41]. Protein concentration was determined by the Bradford method.

\subsubsection{Molecular Weight Determination}

The molecular weight of purified protein was determined by sodium dodecyl sulfatepolyacrylamide gel electrophoresis (SDS-PAGE) using 12\% gel according to Laemmly (1970). The standard proteins were as follows: beta-galactosidase $(116 \mathrm{kDa})$, bovine serum albumin (66 kDa), ovalbumin (45 kDa), lactate dehydrogenase (35 kDa), REase Bsp98I (25 kDa), beta-lactoglobulin $(18.4 \mathrm{kDa})$, lysozyme $(14.4 \mathrm{kDa})$.

\subsection{Humic Acids Preparations}

\subsubsection{Extraction and Purification of HA}

Humic acids from Retisol (southern taiga zone, Moscow region, 56.228278, 37.953300), compost and peat (Merck preparation) were used. The extraction and purification procedures of Retisol HA and peat HA were described in [42-44] respectively. Compost HA was obtained from 10-year old compost. Compost was prepared from meadow vegetation and fallen leaves of a mixed forest (birch, oak, maple, spruce), under which Retisol soil was formed. Extraction of $\mathrm{HA}$ was performed using $0.1 \mathrm{M} \mathrm{NaOH}$ and $\mathrm{N}_{2}$ atmosphere and a soil-to-solution ratio was 1:5. HA was precipitated by $6 \mathrm{M} \mathrm{HCl}(\mathrm{pH}<2)$ and centrifuged $(4000 \times g, 10 \mathrm{~min})$, FA fraction was discarded, HA was washed with distilled water and redissolved in $0.1 \mathrm{M} \mathrm{NaOH}$ under $\mathrm{N}_{2} ; \mathrm{pH}$ of the solution was adjusted to 7.0 by $6 \mathrm{M} \mathrm{HCl}$ and HA was purified by vacuum membrane filtration through $0.45 \mu \mathrm{m}$ and $0.22 \mu \mathrm{M}$ filters (Vladipor, Vladimir, Russia).

\subsubsection{Characterization of the HA}

The elemental composition of the HA was obtained on Vario-EL III elemental analyzer (Elementar, Langenselbold, Hesse, Germany). The ash content was determined by ashing of HA at $800{ }^{\circ} \mathrm{C}$ in a muffle. The solution-state ${ }^{13} \mathrm{C}-\mathrm{NMR}$ spectra of the HA were recorded on a Bruker Avance 400 spectrophotometer (Bruker, Billerica, MA, USA) as described 
previously [42]. The ${ }^{13} \mathrm{C}-\mathrm{NMR}$ assignments were made by integration of spectral regions according to [45].

\subsection{Reaction of Laccase with Humic Acids}

Interaction of laccase with HAs was carried out in buffer A at $30^{\circ} \mathrm{C}$. Laccase was added to the reaction mixture in an amount of $0.1 \mathrm{U} / \mathrm{mL}$ and the concentration of $\mathrm{HA}$ was $1 \mathrm{mg} / \mathrm{mL}$. To study the transformation of the HA with the culture liquid of the fungus, we used the culture liquid taken at the maximum activity of the laccase. The culture liquid was mixed with buffer A, the final concentration of laccase was $0.75 \mathrm{U} / \mathrm{mL}$ and humic acids concentration was $1 \mathrm{mg} / \mathrm{mL}$. The reference incubation mixture contained $2 \mathrm{mM}$ of $\mathrm{NaN}_{3}$ (laccase inhibitor). After $48 \mathrm{~h}$ of the reaction, molecular weight distributions of HA acids were analyzed by gel filtration on Sephadex G-75 gel using Bio-Logic LP system (Bio-Rad, Hercules, CA, USA). $0.025 \mathrm{M}$ Tris- $\mathrm{HCl}$ buffer ( $\mathrm{pH}$ 8.2) with addition of $0.05 \mathrm{M} \mathrm{NaCl}$ and $0.1 \%$ SDS was used as an eluent. Separation conditions and analysis details were similar to those previously described [27].

\section{Results}

\subsection{Production of Laccase}

The conditions of laccase production in zygomycetes are poorly studied. We have tested three different media and the effect of inducers, introduced in each medium, on laccase production by M. elasson.

The fungus M. elasson produced laccase during its growth on Medium 1 without inducers. Laccase activity in the culture liquid appeared on the third day of growth, reached a maximum (158 U/1) on day 10, and then decreased (Figure 1).

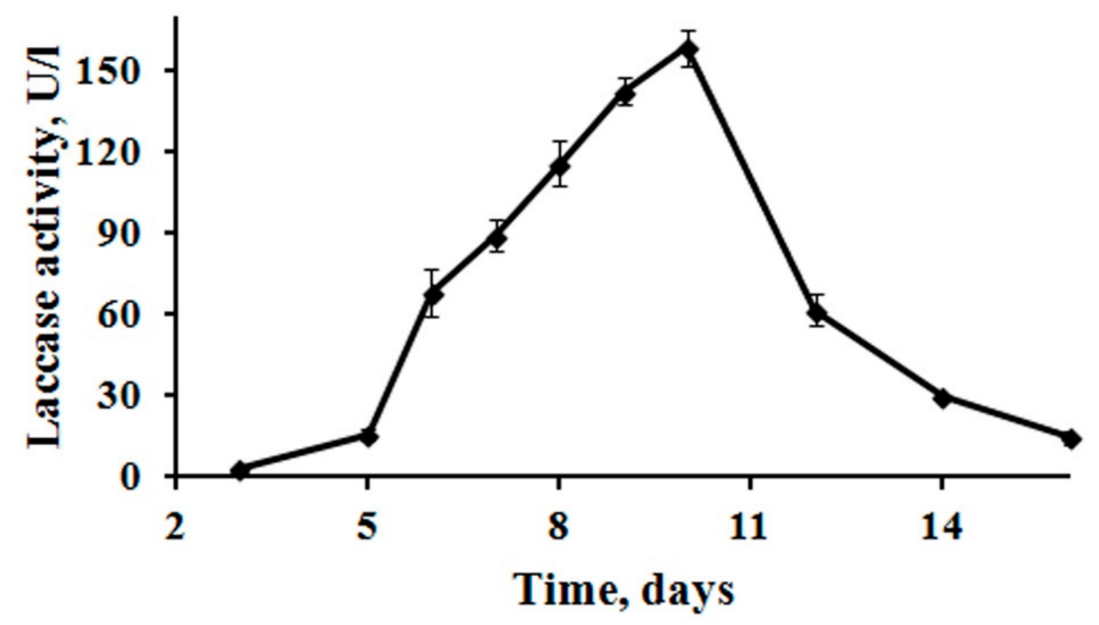

Figure 1. Production of laccase by M. elasson during growth on medium 1.

To optimize the production of laccase by M. elasson on Medium 1 we investigated the effect of some substances, often used as inducers of laccase in fungi, on the production of the enzyme. The following substances were used as inductors: 2,5-xylidine, guaiacol (2-methoxyphenol), 2,6-DMP, ferulic acid, veratrole alcohol (3,4-dimethoxybenzyl alcohol), vanillic acid, anthranilic acid (2-aminobenzoic acid), syringic acid (4-hydroxy3,5-dimethoxybenzoic acid), gallic acid (3,4,5-trihydroxybenzoic acid) and $\mathrm{Cu}^{2+}$ or $\mathrm{Mn}^{2+}$ ions. None of these substances resulted in an increase in laccase production. Moreover, 2.5-xylidine completely suppressed the activity of laccase, while $\mathrm{CuSO}_{4}$ suppressed the growth of the fungus at a concentration of $0.5 \mathrm{mM}$.

Production of laccase by fungi can also be regulated by a nitrogen or carbon source, as well as by nitrogen concentration. Therefore, we studied the production of laccase by the fungus in the media with carbon and nitrogen sources other than in medium 1 . Medium 2 contained glucose as a carbon source and peptone, yeast extract and $\left(\mathrm{NH}_{4}\right)_{2} \mathrm{SO}_{4}$ as nitrogen sources. Medium 3 also contained glucose along with $\mathrm{NH}_{4} \mathrm{NO}_{3}$ and $\alpha$-asparagine. Medium 
3 was used in two variants-with high or low nitrogen (HN or LN). The effect of inducers on production of laccase in Media 2 and 3 has also been studied. Laccase production in each of these media was not observed either in the presence of the inducers or without them.

\subsection{Properties of Laccase}

Laccase was purified from the culture liquid of the fungus. Laccase was obtained in an electrophoretically homogeneous state (Figure 2). The molecular weight (MW) of the laccase obtained on the basis of SDS-PAGE data was $51.75 \mathrm{kDa}$. The enzyme catalyzed the oxidation of different substrates typical of laccase with different efficiencies (Table 1). Electron donors ABTS and $\mathrm{K}_{4}\left[\mathrm{Fe}(\mathrm{CN})_{6}\right]$ were most efficiently oxidized. Phenolic compounds, electron and proton donors were oxidized less efficiently. L-tyrosine was not oxidized by the enzyme. Laccase activity was completely inhibited by $1 \mathrm{mM} \mathrm{NaN}_{3}$ and $10 \mathrm{mM}$ NaF. The optimum value of the reaction rate depending on $\mathrm{pH}$ was determined for ABTS and 2.6 DMP. The maximum reaction rate was observed with ABTS at $\mathrm{pH} 3.0$ and with 2.6 DMP at pH 5.0 (Figure 3). The enzyme was more stable in a weakly acidic medium at $\mathrm{pH} 3-6$. The maximum reaction rate was observed at $70{ }^{\circ} \mathrm{C}$. The enzyme showed moderate thermal stability: it retained about $7 \%$ of its activity for an hour at $60{ }^{\circ} \mathrm{C}$, and was inactivated by $97 \%$ within $10 \mathrm{~min}$ at $70{ }^{\circ} \mathrm{C}$.

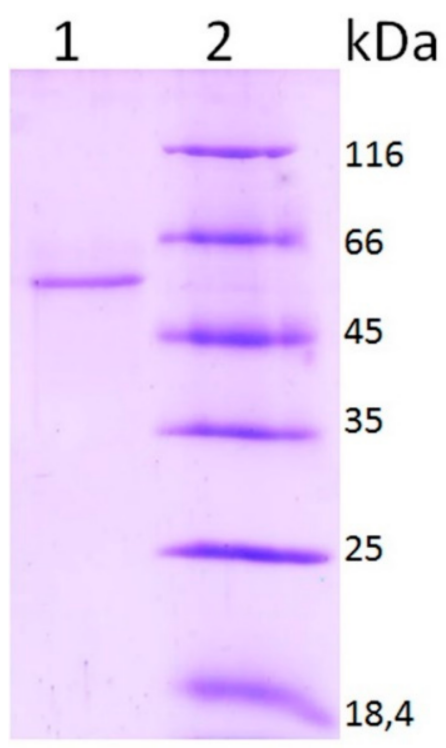

Figure 2. SDS-PAGE data of the purified M. elasson laccase preparation.

Lane 1-laccase preparation, lane 2-molecular weight markers.

Table 1. Catalytic constants of M. elasson laccase for some substrates.

\begin{tabular}{cccc}
\hline Substrate & $\mathbf{K m}, \boldsymbol{\mu M}$ & $\mathbf{k}_{\mathbf{k a t}}, \mathbf{s}^{\mathbf{- 1}}$ & $\begin{array}{c}\mathbf{k}_{\mathbf{k a t}} / \mathbf{K m}, \\
\boldsymbol{\mu} \mathbf{M}^{-\mathbf{1}} \times \mathbf{s}^{\mathbf{- 1}}\end{array}$ \\
\hline ABTS & $32.7 \pm 1.7$ & $41.6 \pm 1.5$ & 1.27 \\
$\mathrm{~K}_{4}\left[\mathrm{Fe}(\mathrm{CN})_{6}\right]$ & $107 \pm 4.3$ & $40.5 \pm 1.6$ & 0.38 \\
2,6-dimethoxyphenol & $35.9 \pm 2.1$ & $1.65 \pm 0.007$ & $4.6 \times 10^{-2}$ \\
Guaiacol & $49.3 \pm 6.5$ & $0.93 \pm 0.01$ & $1.8 \times 10^{-2}$ \\
Hydroquinone & $413 \pm 30$ & $9.43 \pm 0.3$ & $2.2 \times 10^{-2}$ \\
\hline
\end{tabular}

The experimental data on the measurement of kinetic constants are given in Supplementary Materials—supplement kinetic.xlsx. 

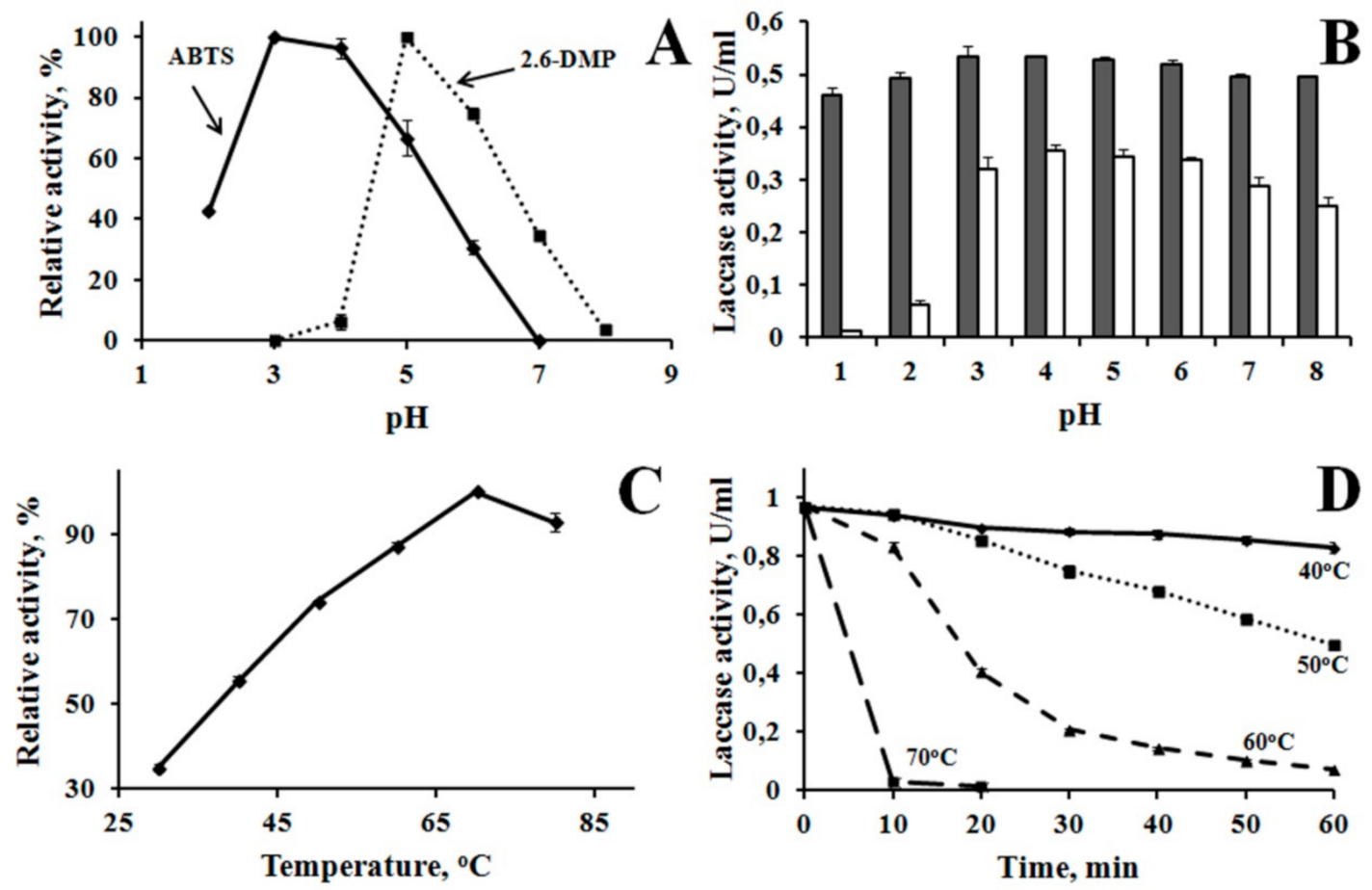

Figure 3. Properties of M. elasson laccase. (A)—optimum $\mathrm{pH},(\mathbf{B})-\mathrm{pH}$ stability: gray bars—initial activity, white barslaccase activity after 4 days. (C) - temperature optimum of the reaction, (D) - thermostability at $40-70{ }^{\circ} \mathrm{C}$. The experimental data presented in Supplementary Materials_-"supplement properties.xlsx".

\subsection{Humic Acids}

Humic acid preparations used in the study were of low ash content (1.9-2.6\% ash). Preparations from Retisol and Compost were quite similar by elemental composition (Table 2) while Peat HA was depleted with nitrogen. The H:C ratio used as a rough measure of the degree of aliphaticity and $\mathrm{O}: \mathrm{C}$ ratios used as a measure of an oxidation state are comparable in all three HA under study.

Table 2. Elemental composition of the humic acids.

\begin{tabular}{ccccccccc}
\hline Sample & & \multicolumn{3}{c}{ Content, Mass\%/Atomic\% } & \multicolumn{3}{c}{ Atomic Ratios } \\
& Ash, \% & C & H & N & O & H:C & O:C & C:N \\
\hline 1 Retisol HA & 2.6 & $52.9 / 35.3$ & $5.2 / 42.1$ & $4.5 / 2.6$ & $40.0 / 20.0$ & 1.2 & 0.6 & 13.7 \\
Compost HA & 2.0 & $51.8 / 38.4$ & $4.0 / 35.5$ & $5.2 / 3.3$ & $41.0 / 22.8$ & 0.9 & 0.6 & 11.7 \\
2 Peat HA & 1.9 & $51.2 / 35.9$ & $4.8 / 40.7$ & $2.8 / 1.7$ & $41.2 / 21.7$ & 1.1 & 0.6 & 21.1 \\
\hline
\end{tabular}

The ${ }^{13} \mathrm{C}-\mathrm{NMR}$ data of HA are listed in Table 3. The spectral range assignments were made according to [45]. The spectral range from 0 to $109 \mathrm{ppm}$ is attributed to carbon in aliphatic fragments and can be splitted into following regions-carbon of alkyl chains (0-48 ppm); carbon of alkoxide groups $\mathrm{CH}_{\mathrm{n}}-\mathrm{O}$ (including $\mathrm{CH}_{3} \mathrm{O}$ groups in lignin structures) and $\mathrm{CH}_{2}-\mathrm{N}$ groups (48-65 ppm); carbon of $\mathrm{CH}-\mathrm{O}$ groups in saccharide structure (64-90 ppm); carbon bonded by single bonds to heteroatoms (O-C-O, 90-109 ppm). In humic acids this is mainly acetal carbon in cyclic saccharides. The spectral range of $109-164 \mathrm{ppm}$ is attributed to aromatic structures-aromatic $\mathrm{C}$ bonded with $\mathrm{H}$ or $\mathrm{C}$ atoms (Car-H, C; 109-145 ppm) and aromatic carbon substituted by heteroatoms (Car-O, N; 145-164 ppm). The Car-O groups include $\mathrm{C}_{\mathrm{ar}}-\mathrm{OCH}_{3}$ and $\mathrm{C}_{\mathrm{ar}}-\mathrm{OH}$ in lignin. The spectral range $164-187$ is attributed to $C$ of carboxyl, ester and amide groups $((\mathrm{C}=\mathrm{O})-\mathrm{O}, \mathrm{N})$, while the range 187-220 is attributed to ketone and quinone groups.

Comparison of the HA by their ${ }^{13} \mathrm{C}-\mathrm{NMR}$ data (Table 3) shows that Retisol HA is depleted by $\mathrm{CH}_{n}$-groups and enriched by aliphatic groups substituted by heteroatoms 
(48-90 ppm range) in comparison to compost and peat HA. The amount of polysaccharide fragments in HA increase in the order HA Retisol-compost-peat. Retisol HA contains somewhat higher amount of O-substituted aromatic C (145-164 ppm) in comparison to compost and peat HA. In spite of some differences in the distribution of aliphatic and aromatic $\mathrm{C}$ atoms among structural fragments, the ratio of aromatic to aliphatic $\mathrm{C}$ is similar in all three HA studied.

Table 3. Distribution of carbon atoms by structural fragments in the HA (solution-state 13C-NMR spectroscopy), \% of the total area of the spectrum.

\begin{tabular}{|c|c|c|c|c|c|c|c|c|c|}
\hline \multicolumn{10}{|c|}{ Spectral Region, ppm/Structural Group } \\
\hline \multirow[b]{2}{*}{ Sample } & \multicolumn{4}{|c|}{ Aliphatic Fragments } & \multirow{2}{*}{$\begin{array}{c}\text { Aroma } \\
\text { Fragme }\end{array}$} & \multicolumn{3}{|c|}{$\begin{array}{c}\text { Carboxyls, Ketones and } \\
\text { Quinones }\end{array}$} & \multirow[b]{2}{*}{${ }^{2} \mathrm{Car} / \mathrm{Cal}$} \\
\hline & $\begin{array}{l}0-48 \\
\mathrm{CH}_{\mathrm{n}}\end{array}$ & $\begin{array}{l}48-64 \\
\mathrm{CH}_{\mathrm{n}} \mathrm{O}\end{array}$ & $\begin{array}{l}64-90 \\
\mathrm{CHO}\end{array}$ & $\begin{array}{c}90-109 \\
\text { OCO }\end{array}$ & & $\begin{array}{c}145-164 \\
\mathrm{C}_{\mathrm{ar}} \mathrm{O}\end{array}$ & $\begin{array}{c}164-187 \\
\text { COO }\end{array}$ & $\begin{array}{c}187-220 \\
\mathrm{C}=\mathrm{O}\end{array}$ & \\
\hline${ }^{1}$ Retisol HA & 13.0 & 10.0 & 13.0 & 3.0 & 21.0 & 13.0 & 20.0 & 8.0 & 0.9 \\
\hline $\begin{array}{l}\text { Compost } \\
\text { HA }\end{array}$ & 18.0 & 8.6 & 9.1 & 4.3 & 26.1 & 9.5 & 18.9 & 5.5 & 0.9 \\
\hline Peat HA & 17.8 & 9.6 & 9.7 & 8.6 & 26.8 & 8.3 & 15.2 & 3.9 & 0.8 \\
\hline
\end{tabular}

${ }^{1}$ HART preparation [42]; ${ }^{2}$ aliphatic $C$ region-0-109 $\mathrm{ppm}$, aromatic $\mathrm{C}$ region-109-164 ppm.

\subsection{Interaction of Laccase with Humic Acids}

The effect of $M$. elasson laccase on HA was studied using the culture liquid and purified enzyme. Under the action of the culture liquid, the amount of the high-molecular fraction with MW > $80 \mathrm{kDa}$ decreased with a corresponding increase in the low-molecular fraction of humic acids with MW of about $20 \mathrm{kDa}$ (Figure 4A-C). There was also an increase in the fraction with MW of less than $10 \mathrm{kDa}$ eluted in the total void volume. In the presence of $\mathrm{NaN}_{3}$, no transformation of HA occurred, which indicates that laccase was responsible for the transformation process. Changes in the MW of HA under the action of purified laccase were similar to the changes that occurred under the action of the culture liquid containing laccase. In the presence of laccase, a decrease in the amount of high molecular weight fraction with MW > $80 \mathrm{kDa}$ was observed while the amount of material with MW of about $20 \mathrm{kDa}$ and less than $10 \mathrm{kDa}$ increased (Figure 4D-F). This indicates a process of depolymerization of humic acids. 


\section{Culture liquid}
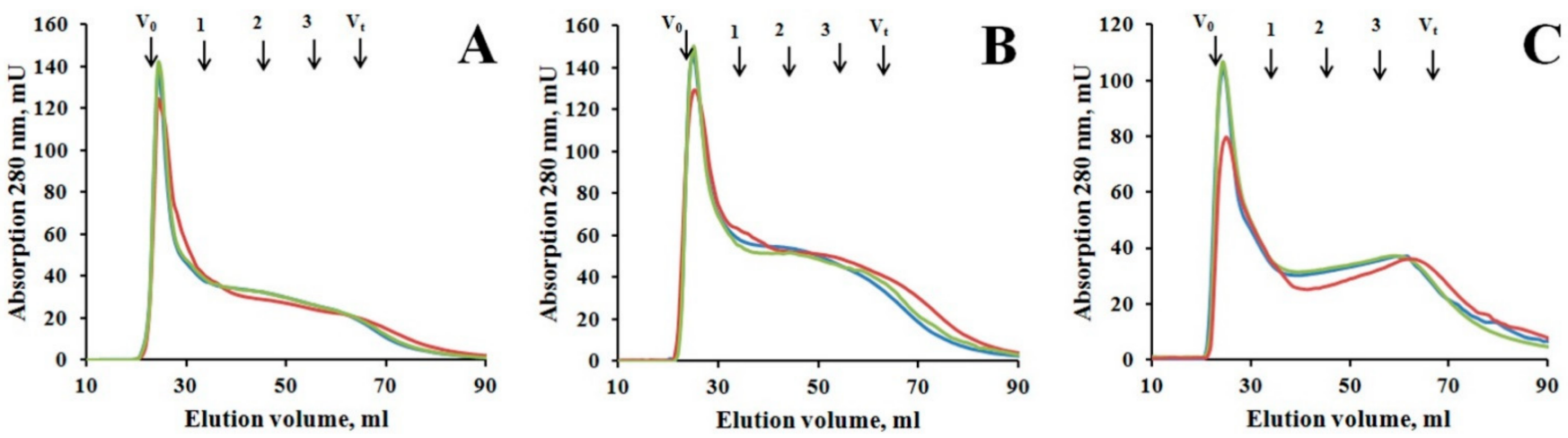

\section{Purified enzyme}
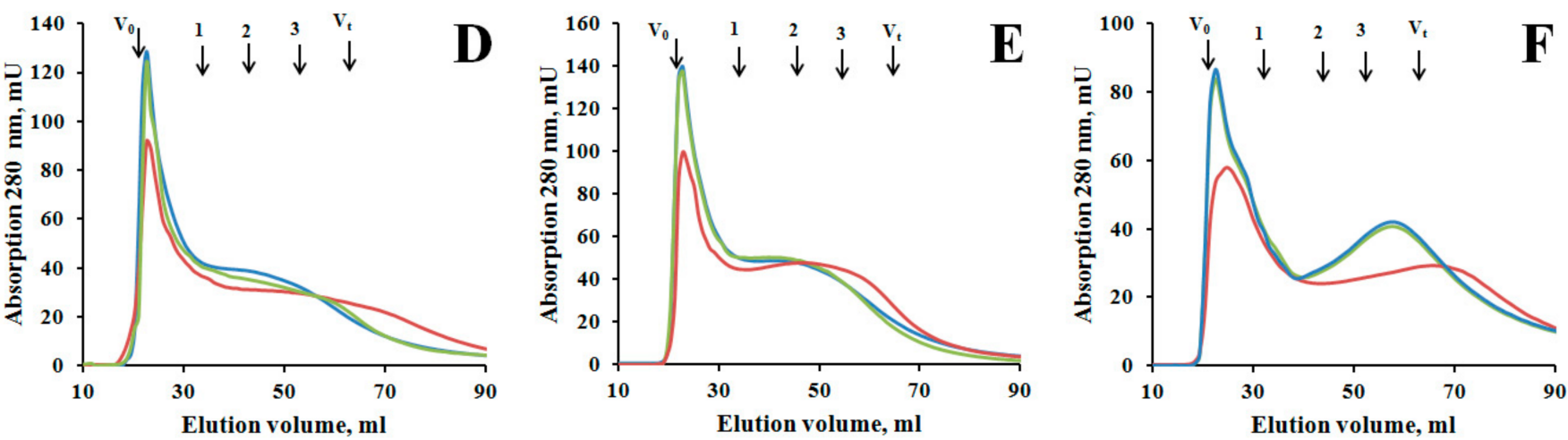

Figure 4. Transformation of the HA by laccase-containing culture liquid of M. elasson (A-C) and by the purified laccase (D-F): (A or D)-Retisol HA, (B or E)—compost HA, (C of F)-Merck HA. The green line is initial HA, the blue line is the reference with inactivated laccase, the red line is transformation of HA by laccase. Arrows indicate the void volume $\left(\mathrm{V}_{0}>80 \mathrm{kDa}\right)$, the total void volume $\left(\mathrm{V}_{\mathrm{t}}<5 \mathrm{kDa}\right), 1$ - bovine serum albumin $(66 \mathrm{kDa}), 2$-carbonic anhydrase $(29 \mathrm{kDa})$, 3-cytochrome C (12.4 kDa). The experimental data presented in Supplementary Materials_-"supplement gel-filtration culture liqued.xlsx" and "supplement gel-filtration laccase.xlsx".

\section{Discussion}

\subsection{Production of Laccase by Mortierella Elasson}

Fungal laccase is an inducible enzyme. In the presence of inducers, enzyme production often increases significantly. In basidiomycete ligninolytic fungi this effect is expressed to a large extent. For example, in Trametes pubescens and Pleurotus ostreatus, the presence of copper ions caused an increase in laccase production to dozens of times [46,47]. The use of aromatic compounds also caused an increase in the synthesis of laccase. In Ganoderma lucidum, veratryl alcohol caused laccase induction [48], while in Pycnoporus cinnabarinus laccase production increased in the presence of 2.5-xylidine [49]. This example shows that there is no universal inducer equally effective with all fungi, since in P. cinnabarinus 2.5-xylidine caused induction of laccase, and in G. lucidum it did not [50]. In the basidiomycete fungus Phlebia floridensis laccase was produced better in the presence of organic nitrogen sources than inorganic ones [51]. In Marasmiellus palmivorus, the combination of nitrogen and carbon sources, glucose/casein, caused the highest laccase production [52]. Laccase production can also increase under conditions of low nitrogen concentration [53]. Similarly, laccase can be induced in ascomycete fungi. Aromatic compounds and copper ions induced laccase in ascomycetes [41,54]. However, in Penicillium chrysogenum some 
inductors suppressed the production of laccase [55]. Likewise, the source of nitrogen and carbon may have an important role in the production of laccase by ascomycete fungi [56].

In this work, the use of inducers, changes in nitrogen or carbon sources and nitrogen concentration were ineffective for the induction of laccase by M. elasson. However, laccase of $M$. elasson is not a constitutive enzyme, since it was produced extracellularly on Medium 1 containing soy flour. It is possible that unknown components of soy flour acted as an inducer. Induction of laccase can be caused by natural substrates of unknown composition [57]. The laccase of zygomycetous fungus $M$. circinelloides was induced by copper ions on a medium with kraft lignin - a substance with a completely unknown composition [34]. The factors causing laccase production in M. elasson require further study.

\subsection{Properties of Laccase of M. elasson}

Laccase from $M$. elasson exhibited properties typical of laccase-it oxidized phenolic substances and ABTS, and was inhibited by $\mathrm{NaN}_{3}$ and $\mathrm{NaF}$, which bind to the coppercontaining active center of the enzyme [6]. ABTS and $\mathrm{K}_{4}\left[\mathrm{Fe}(\mathrm{CN})_{6}\right]$ were oxidized by the enzyme more efficiently than phenolic compounds, which is also found in laccases of some fungi [7]. The pH optima of oxidation of ABTS and 2.6 DMP were different and lay in the acidic region, which is also characteristic of laccases, since the mechanism of oxidation of electron donors (ABTS) and phenolic compounds is different [58]. In another form of laccase-two-domain bacterial laccases, the optimum oxidation of phenolic compounds is in the range of alkaline $\mathrm{pH}$ [17]. Nevertheless, a fungal laccase with a weakly alkaline optimum of phenolic compound oxidation ( $\mathrm{pH}$ 8.0) was described [59]. The $\mathrm{pH}$ optima of laccase from zygomycetous fungus $M$. circinelloides was also in the acidic $\mathrm{pH}$ range ( $\mathrm{pH}$ 5.0). The enzyme from M. elasson did not show great thermal stability, which is typical for fungal laccases [60,61]. Thermostable fungal laccase was described in Pycnoporus sanguineus, which retained activity for $2 \mathrm{~h}$ at $80{ }^{\circ} \mathrm{C}$ [62].

\subsection{Transformation of Humic Acids}

Fungi effectively decompose organic debris and humus components. Oxidizing enzymes, including laccase, play an important role in this process. It was shown that several basidiomycete fungi effectively decompose $\mathrm{HA}$ in vivo and this correlated with the production of laccase [63]. Production of laccase by the white-rot fungus Lentinus (Panus) tigrinus was induced by HA [11]. The HA were decomposed in the liquid culture of this fungus in the presence of laccase as effectively as in the presence of more powerful oxidant-a versatile peroxidase [11]. Fungal mycelium has a significant effect on their transformation [11,64]. Polymerization reactions of low molecular products of HA degradation occur on fungal cells in the presence of laccase, while effective depolymerization and decolorization of mycelium-bound HA components occurs in the presence of versatile peroxidase [11]. In order to exclude the effect of the mycelium on HA degradation and elucidate the role of extracellular laccase in this process, we studied the transformation of HA by the culture liquid of the fungus $M$. elasson without mycelium.

Compost HA used in this study was expected to represent fresher (less humified) material in comparison to Retisol HA. Indeed, according to ${ }^{13} \mathrm{C}-\mathrm{NMR}$ data, HA from Retisol is more oxidized, containing a larger number of carboxyl groups and O-substituted aromatic and aliphatic fragments. The peat HA preparation contains the lowest amount of $\mathrm{O}$ substituted aromatics in comparison to the two other HA (Table 3). Despite the differences in oxidation state, laccase of $M$. elasson caused similar changes in all three HA preparationsdepolymerization reaction occurred (Figure 4). Depolymerization was more intensive in the presence of purified enzyme (Figure 4D-F) than in the cell-free culture liquid (Figure 4A-C). This is consistent only partially with other studies on in vitro transformation of HA by laccases. The purified laccase of the white-rot fungus L. tigrinus transformed HA preparations in two different ways-either polymerizing or depolymerizing them [10]. Laccase from ascomycete Chaetomium thermophilium polymerized HA from compost [65]. Bacterial two-domain laccases, capable of transforming HA at alkaline $\mathrm{pH}$ values, also polymerized 
HA and catalyzed their copolymerization with low-molecular phenolic compounds [27]. Exclusively polymerization reactions shown for two-domain laccases are possibly associated with a low redox potential of this enzyme [66], so that bacterial laccases are not able of degrading macromolecular components of humus. Thus, laccase catalyzes both polymerization and depolymerization reactions. The different action of laccase on various preparations of HA is possibly related to the difference in molecular weight distributions of HA from different sources. For fungal laccases, polymerization-depolymerization equilibrium exists: substrates of low molecular weight (including monomers) polymerize, while high-molecular weight substrates depolymerize [12]. However, such a dependency is not always observed with HA. In the study with $P$. tigrinus laccase it was shown that those fractions of HA were affected by the enzyme that caused lower inhibitory effect on laccase, i.e., fractions were less hydrophobic [10]. Interestingly, the same peat HA preparation as the one used in this study was polymerized by P. tigrinus laccase [10], while in this study this preparation was depolymerized by M. elasson laccase even more intensively than the two other HA (Figure 4). These data suggest that laccases of different producers differ significantly in their action on humus constituents.

\section{Conclusions}

Zygomycete laccase was purified for electrophoretic homogeneity for the first time. The results of the study substantially extend our knowledge of HA transformation by laccases. It was shown for the first time that laccase of zygomycete fungus can depolymerize some HA even more effectively than laccase from lignin-degrading fungi (e.g., P. tigrinus). Zygomycete fungi and their oxidative enzyme systems require attention as potentially important contributors to turnover processes of polyphenolic humus components.

Supplementary Materials: The following are available online at https:/ /www.mdpi.com/article/10 .3390 /agronomy11112169/s1. Additional files contain initial experimental data. File "supplement properties.xlsx" contains data on studying the properties of laccase; file "supplement kinetic.xlsx" contains data on measurement of kinetic constants of the enzyme; file "supplement gel-filtration culture liqued.xlsx" contains gel filtration data for transformation of HA by culture liquid; file "supplement gel-filtration laccase.xlsx" contains gel filtration data for transformation of HA by purified enzyme.

Author Contributions: Conceptualization, A.L. (Alexander Lisov) and A.Z.; methodology, A.L. (Alexander Lisov); software, A.L. (Alexander Lisov); validation, all authors; formal analysis, A.L. (Alexander Lisov), O.B., A.K., A.Z.; investigation, A.L. (Alexander Lisov), O.B., A.K.; resources, A.L. (Alexander Lisov), A.Z.; data curation, A.L. (Alexander Lisov); writing-original draft preparation, A.L. (Alexander Lisov), A.Z.; writing-review and editing, A.L. (Alexander Lisov), A.Z., A.L. (Alexey Leontievsky); visualization, A.L. (Alexander Lisov); supervision, A.L. (Alexander Lisov), A.L. (Alexey Leontievsky); project administration, A.L., A.Z.; funding acquisition, A.Z., A.L. (Alexander Lisov). All authors have read and agreed to the published version of the manuscript.

Funding: This research was funded by RSF grant No. 17-14-01207 (laccase purification, experiments with HA) and by the State budget topic of soil chemistry department, MSU (121040800154-8 (compost HA extraction, purification and characterization).

Institutional Review Board Statement: Not applicable.

Informed Consent Statement: Not applicable.

Conflicts of Interest: The authors declare no conflict of interest. The funders had no role in the design of the study; in the collection, analyses, or interpretation of data; in the writing of the manuscript, or in the decision to publish the results.

\section{References}

1. Batjes, N.H. Total carbon and nitrogen in the soils of the world. Eur. J. Soil Sci. 2014, 65, 10-21. [CrossRef]

2. Schmidt, M.W.I.; Torn, M.S.; Abiven, S.; Dittmar, T.; Guggenberger, G.; Janssens, I.A.; Kleber, M.; Kogel-Knabner, I.; Lehmann, J.; Manning, D.A.C.; et al. Persistence of soil organic matter as an ecosystem property. Nature 2011, 478, 49-56. [CrossRef] [PubMed] 
3. Semenov, V.M.; Tulina, A.S.; Semenova, N.A.; Ivannikova, L.A. Humification and nonhumification pathways of the organic matter stabilization in soil: A review. Eurasian Soil Sci. 2013, 46, 355-368. [CrossRef]

4. Stevenson, F.J. Humus Chemistry: Genesis, Composition, Reactions, 2nd ed.; John Wiley and Sons: Hoboken, NJ, USA, $1994 ;$ p. 512.

5. Zavarzina, A.G.; Lisov, A.A.; Zavarzin, A.A.; Leontievsky, A.A. Fungal oxidoreductases and humification in forest soils. In Soil Enzymology; Shukla, G., Varma, A., Eds.; Springer: Berlin/Heidelberg, Germany, 2010; Volume 22, pp. 207-228. [CrossRef]

6. Solomon, E.I.; Uma, M.S.; Machonkin, T.E. Multicopper oxidases and oxygenases. Chem. Rev. 1996, 96, 2563-2606. [CrossRef]

7. Baldrian, P. Fungal laccases-occurrence and properties. FEMS Microbiol. Rev. 2006, 30, 215-242. [CrossRef]

8. Gorbacheva, M.; Morozova, O.; Shumakovich, G.; Streltsov, A.; Shleev, S.; Yaropolov, A. Enzymatic oxidation of manganese ions catalysed by laccase. Bioorg. Chem. 2009, 37, 1-5. [CrossRef]

9. Grinhut, T.; Hadar, Y.; Chen, Y. Degradation and transformation of humic substances by saprotrophic fungi: Processes and mechanisms. Fungal Biol. Rev. 2007, 21, 179-189. [CrossRef]

10. Zavarzina, A.G.; Leontievsky, A.A.; Golovleva, L.A.; Trofimov, S.Y. Biotransformation of soil humic acids by blue laccase of Panus tigrinus 8/18: An in vitro study. Soil Biol. Biochem. 2004, 36, 359-369. [CrossRef]

11. Zavarzina, A.G.; Lisov, A.V.; Leontievsky, A.A. The role of ligninolytic enzymes laccase and a versatile peroxidase of the white-rot fungus Lentinus tigrinus in biotransformation of soil humic matter: Comparative in vivo study. J. Geophys. Res. Biogeosciences 2018, 123, 2727-2742. [CrossRef]

12. Thurston, C.F. The structure and function of fungal laccases. Microbiology 1994, 140, 19-26. [CrossRef]

13. Mayer, A.M.; Harel, E. Polyphenol oxidases in plants. Phytochemistry 1979, 18, 193-215. [CrossRef]

14. Dittmer, N.T.; Gorman, M.J.; Kanost, M.R. Characterization of endogenous and recombinant forms of laccase-2, a multicopper oxidase from the tobacco hornworm, Manduca sexta. Insect Biochem. Mol. Biol. 2009, 39, 596-606. [CrossRef]

15. Otto, B.; Schlosser, D. First laccase in green algae: Purification and characterization of an extracellular phenol oxidase from Tetracystis aeria. Planta 2014, 240, 1225-1236. [CrossRef]

16. Ece, S.; Lambertz, C.; Fischer, R.; Commandeur, U. Heterologous expression of a Streptomyces cyaneus laccase for biomass modification applications. AMB Express 2017, 7, 1-12. [CrossRef]

17. Machczynski, M.C.; Vijgenboom, E.; Samyn, B.; Canters, G.W. Characterization of SLAC: A small laccase from Streptomyces coelicolor with unprecedented activity. Protein Sci. 2004, 13, 2388-2397. [CrossRef]

18. Arregui, L.; Ayala, M.; Gómez-Gil, X.; Gutiérrez-Soto, G.; Hernández-Luna, C.E.; de Los Santos, M.H.; Levin, L.; Rojo-Domínguez, A.; Romero-Martínez, D.; Saparrat, M.C.; et al. Laccases: Structure, function, and potential application in water bioremediation. Microb. Cell Fact. 2019, 18, 1-33. [CrossRef]

19. Pourcel, L.; Routaboul, J.M.; Cheynier, V.; Lepiniec, L.; Debeaujon, I. Flavonoid oxidation in plants: From biochemical properties to physiological functions. Trends Plant Sci. 2007, 12, 29-36. [CrossRef]

20. Liu, Q.; Luo, L.; Zheng, L. Lignins: Biosynthesis and biological functions in plants. Int. J. Mol. Sci. 2018, 19, 335. [CrossRef]

21. Tsai, H.F.; Wheeler, M.H.; Chang, Y.C.; Kwon-Chung, K.J. A developmentally regulated gene cluster involved in conidial pigment biosynthesis in Aspergillus fumigatus. J. Bacteriol. 1999, 181, 6469-6477. [CrossRef]

22. Frases, S.; Salazar, A.; Dadachova, E.; Casadevall, A. Cryptococcus neoformans can utilize the bacterial melanin precursor homogentisic acid for fungal melanogenesis. Appl. Environ. Microbiol. 2007, 73, 615-621. [CrossRef]

23. Singh, R.; Hu, J.; Regner, R.; Round, J.W.; Ralph, J.; Saddler, J.N.; Eltis, L.D. Enhanced delignification of steam-pretreated poplar by a bacterial laccase. Sci. Rep. 2017, 7, 42121. [CrossRef] [PubMed]

24. Gaitan, I.J.; Medina, S.C.; González, J.C.; Rodríguez, A.; Espejo, A.J.; Osma, J.F.; Sarria, V.; Alméciga-Díaz, C.J.; Sánchez, O.F. Evaluation of toxicity and degradation of a chlorophenol mixture by the laccase produced by Trametes pubescens. Bioresour. Technol. 2011, 102, 3632-3635. [CrossRef] [PubMed]

25. Eichlerová, I.; Šnajdr, J.; Baldrian, P. Laccase activity in soils: Considerations for the measurement of enzyme activity. Chemosphere 2012, 88, 1154-1160. [CrossRef] [PubMed]

26. De Nobili, M.; Bravo, C.; Chen, Y. The spontaneous secondary synthesis of soil organic matter components: A critical examination of the soil continuum model theory. Appl. Soil Ecol. 2020, 154, 103655. [CrossRef]

27. Trubitsina, L.I.; Lisov, A.V.; Belova, O.V.; Trubitsin, I.V.; Demin, V.V.; Konstantinov, A.I.; Zavarzina, A.G.; Leontievsky, A.A. Transformation of low molecular compounds and soil humic acid by two domain laccase of Streptomyces puniceus in the presence of ferulic and caffeic acids. PLoS ONE. 2020, 15, e0239005. [CrossRef]

28. Egidi, E.; Delgado-Baquerizo, M.; Plett, J.M.; Wang, J.; Eldridge, D.J.; Bardgett, R.D.; Maestre, F.T.; Singh, B.K. A few Ascomycota taxa dominate soil fungal communities worldwide. Nat. Commun. 2019, 10, 1-9. [CrossRef]

29. Thorn, R.G.; Reddy, C.A.; Harris, D.; Paul, E.A. Isolation of saprophytic basidiomycetes from soil. Appl. Environ. Microbiol. 1996, 62, 4288-4292. [CrossRef]

30. Wu, J.; Choi, J.; Asiegbu, F.O.; Lee, Y.H. Comparative genomics platform and phylogenetic analysis of fungal laccases and multi-copper oxidases. Mycobiology 2020, 48, 373-382. [CrossRef]

31. Spatafora, J.W.; Chang, Y.; Benny, G.L.; Lazarus, K.; Smith, M.E.; Berbee, M.L.; Bonito, G.; Corradi, N.; Grigoriev, I.; Gryganskyi, A.; et al. A phylum-level phylogenetic classification of zygomycete fungi based on genome-scale data. Mycologia 2016, 108, 1028-1046. [CrossRef]

32. Bankolea, P.O.; Semple, K.T.; Jeon, B.H.; Govindwar, S.P. Biodegradation of fluorene by the newly isolated marine-derived fungus, Mucor irregularis strain bpo1 using response surface methodology. Ecotoxicol. Environ. Saf. 2020, 208, 111619. [CrossRef] 
33. Kanmani, P.; Karuppasamy, P. Studies on lignocellulose biodegradation of coir waste in solid state fermentation using Phanerocheate chrysosporium and Rhizopus stolonifer. Afr. J. Biotechnol. 2009, 8, 6880-6887. [CrossRef]

34. Geethanjali, P.A.; Gowtham, H.G.; Jayashankar, M. Optimization of culture conditions for hyper-production of laccase from an indigenous litter dwelling fungus Mucor circinelloides GL1. Environ. Sustain. 2020, 3, 141-146. [CrossRef]

35. Ozimek, E.; Hanaka, A. Mortierella species as the plant growth-promoting fungi present in the agricultural soils. Agriculture 2020, 11, 7. [CrossRef]

36. Sideris, C.P.; Paxton, G.E. A new species of Mortierella. Mycologia 1929, 21, 175-177. [CrossRef]

37. Heinfling, A.; Martinez, A.T.; Martinez, M.J.; Bergbauer, M.; Szewzyk, U. Purification and characterization of peroxidases from the dye-decolorizing fungus Bjerkandera adusta. FEMS Microbiol. Lett. 1998, 428, 43-50. [CrossRef]

38. Wariishi, H.; Valli, K.; Gold, M.H. Manganese(II) oxidation by manganese peroxidase from the basidiomycete Phanerochaete chrysosporium. Kinetic mechanism and role of helators. J. Biol. Chem. 1992, 267, 23688-23695. [CrossRef]

39. Timofeevski, S.L.; Reading, N.S.; Aust, S.D. Mechanisms for protection against inactivation of manganese peroxidase by hydrogen peroxide. Arch. Biochem. Biophys. 1998, 356, 287-295. [CrossRef]

40. Maehly, A.C.; Chance, B. The assay of catalases and peroxidases. In Methods of Biochemical Analysis; Glick, D., Ed.; Interscience: New York, NY, USA, 1954; Volume 1, pp. 357-408.

41. Saito, T.; Hong, P.; Kato, K.; Okazaki, M.; Inagaki, H.; Maeda, S.; Yokogawa, Y. Purification and characterization of an extracellular laccase of a fungus (family Chaetomiaceae) isolated from soil. Enzym. Microb. Technol. 2003, 33, 520-526. [CrossRef]

42. Zavarzina, A.G.; Kravchenko, E.G.; Konstantinov, A.I.; Perminova, I.V.; Chukov, S.N.; Demin, V.V. Comparison of the properties of humic acids extracted from soils by alkali in the presence and absence of oxygen. Eurasian Soil Sci. 2019, 52, 880-891. [CrossRef]

43. Zavarzina, A.G.; Demin, V.V. Acid-base properties of humic acids as seen from potentiometric titration data. Eurasian Soil Sci. 1999, 32, 1246-1256.

44. Zavarzina, A.G.; Demin, V.V.; Nifantieva, T.I.; Shkinev, V.M.; Danilova, T.V.; Spivakov, B.Y. Extraction of humic acids and their fractions in polyethylene glycol-based aqueous biphasic systems. Anal. Chim. Acta 2002, 452, 95-103. [CrossRef]

45. Hertkorn, N.; Permin, A.; Perminova, I.; Kovalevskii, D.; Yudov, M.; Petrosyan, V.; Kettrup, A. Comparative analysis of partial structures of a peat humic and fulvic acid using one- and two-dimensional nuclear magnetic resonance spectroscopy. J. Environ. Qual. 2002, 31, 375-387. [CrossRef] [PubMed]

46. Galhaup, C.; Haltrich, D. Enhanced formation of laccase activity by the white-rot fungus Trametes pubescens in the presence of copper. Appl. Microbiol. Biotechnol. 2001, 56, 225-232. [CrossRef] [PubMed]

47. Giardina, P.; Palmieri, G.; Scaloni, A.; Fontanella, B.; Faraco, V.; Cennamo, G.; Sannia, G. Protein and gene structure of a blue laccase from Pleurotus ostreatus. Biochem. J. 1999, 341, 655-663. [CrossRef]

48. D'Souza, T.M.; Merritt, C.S.; Reddy, C.A. Lignin-modifying enzymes of the white rot basidiomycete Ganoderma lucidum. Appl. Environ. Microbiol. 1999, 65, 5307-5313. [CrossRef]

49. Eggert, C.; Temp, U.; Eriksson, K.E. The ligninolytic system of the white rot fungus Pycnoporus cinnabarinus: Purification and characterization of the laccase. Appl. Environ. Microbiol. 1996, 62, 1151-1158. [CrossRef]

50. Elisashvili, V.; Kachlishvili, E.; Khardziani, T.; Agathos, S.N. Effect of aromatic compounds on the production of laccase and manganese peroxidase by white-rot basidiomycetes. J. Ind. Microbiol. Biotechnol. 2010, 37, 1091-1096. [CrossRef]

51. Arora, D.S.; Rampal, P. Laccase production by some Phlebia species. J. Basic Microbiol. 2002, 42, 295-301. [CrossRef]

52. Schneider, W.; Fontana, R.; Mendonça, S.; Siqueira, F.G.; Dillon, A.J.; Camassola, M. High level production of laccases and peroxidases from the newly isolated white-rot basidiomycete Marasmiellus palmivorus VE111 in a stirred-tank bioreactor in response to different carbon and nitrogen sources. Process Biochem. 2018, 69, 1-11. [CrossRef]

53. Pointing, S.; Jones, E.; Vrijmoed, L. Optimization of laccase production by Pycnoporus sanguineus in submerged liquid culture. Mycologia 2000, 92, 139-144. [CrossRef]

54. Buddhika, U.V.A.; Savocchia, S.; Steel, C.C. Copper induces transcription of BcLCC2 laccase gene in phytopathogenic fungus Botrytis cinerea. Mycology 2020, 11, 48-57. [CrossRef]

55. Rodríguez, A.; Falcón, M.A.; Carnicero, A.; Perestelo, F.; De la Fuente, G.; Trojanowski, J. Laccase activities of Penicillium chrysogenum in relation to lignin degradation. Appl. Microbiol. Biotechnol. 1996, 45, 399-403. [CrossRef]

56. Assavanig, A.; Amornikitticharoen, B.; Ekpaisal, N.; Meevootisom, V.; Flegel, T.W. Isolation, characterization and function of laccase from Trichoderma. Appl. Microbiol. Biotechnol. 1992, 38, 198-202. [CrossRef]

57. Góralczyk-Bińkowska, A.; Jasińska, A.; Długoński, A.; Płociński, P.; Długoński, J. Laccase activity of the ascomycete fungus Nectriella pironii and innovative strategies for its production on leaf litter of an urban park. PLoS ONE 2020, 15, e0231453. [CrossRef]

58. $\mathrm{Xu}, \mathrm{F}$. Effects of redox potential and hydroxide inhibition on the $\mathrm{pH}$ activity profile of fungal laccases. J. Biol. Chem. 1997, 272, 924-928. [CrossRef]

59. Heinzkill, M.; Bech, L.; Halkier, T.; Schneider, P.; Anke, T. Characterization of laccases and peroxidases from woodrotting fungi (family Coprinaceae). Appl. Environ. Microbiol. 1998, 64, 1601-1606. [CrossRef]

60. Wu, Y.R.; Luo, Z.H.; Kwok-Kei Chow, R.; Vrijmoed, L.L. Purification and characterization of an extracellular laccase from the anthracene-degrading fungus Fusarium solani MAS2. Bioresour. Technol. 2010, 65, 4943-4948. [CrossRef] 
61. Nagai, M.; Kawata, M.; Watanabe, H.; Ogawa, M.; Saito, K.; Takesawa, T.; Kanda, K.; Sato, T. Important role of fungal intracellular laccase for melanin synthesis: Purification and characterization of an intracellular laccase from Lentinula edodes fruit bodies. Microbiology 2003, 149, 2455-2462. [CrossRef]

62. Garcia, T.A.; Santiago, M.F.; Ulhoa, C.J. Studies on the Pycnoporus sanguineus CCT-4518 laccase purified by hydrophobic interaction chromatography. Appl. Microbiol. Biotechnol. 2007, 75, 311-318. [CrossRef]

63. Fakoussa, R.; Frost, P. In vivo-decolorization of coal-derived humic acids by laccase-excreting fungus Trametes versicolor. Appl. Microbiol. Biotechnol. 1999, 52, 60-65. [CrossRef]

64. Zahmatkesh, M.; Spanjers, H.; Toran, M.J.; Blánquez, P.; van Lier, J.B. Bioremoval of humic acid from water by white rot fungi: Exploring the removal mechanisms. AMB Express 2016, 6, 1-13. [CrossRef] [PubMed]

65. Chefetz, B.; Chen, Y.; Hadar, Y. Purification and characterization of laccase from Chaetomium thermophilium and its role in humification. Appl. Environ. Microbiol. 1998, 64, 3175-3179. [CrossRef] [PubMed]

66. Olbrich, A.C.; Schild, J.N.; Urlacher, V.B. Correlation between the T1 copper reduction potential and catalytic activity of a small laccase. J. Inorg. Biochem. 2019, 201, 110843. [CrossRef] [PubMed] 